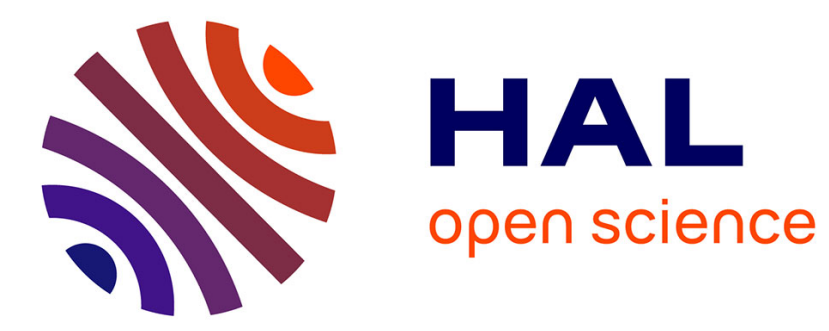

\title{
The Paragraph as Information Technology: How News Traveled in the Eighteenth-Century Atlantic World
}

\author{
Will Slauter
}

\section{To cite this version:}

Will Slauter. The Paragraph as Information Technology: How News Traveled in the EighteenthCentury Atlantic World. Annales HSS, 2012, 67 (2), pp.253 - 78. hal-01446908

\section{HAL Id: hal-01446908 \\ https://hal.science/hal-01446908}

Submitted on 26 Jan 2017

HAL is a multi-disciplinary open access archive for the deposit and dissemination of scientific research documents, whether they are published or not. The documents may come from teaching and research institutions in France or abroad, or from public or private research centers.
L'archive ouverte pluridisciplinaire HAL, est destinée au dépôt et à la diffusion de documents scientifiques de niveau recherche, publiés ou non, émanant des établissements d'enseignement et de recherche français ou étrangers, des laboratoires publics ou privés. 


\title{
The Paragraph \\ as Information Technology \\ How News Traveled in the Eighteenth-Century Atlantic World
}

\author{
Will Slauter
}

In the eighteenth century, gazettes and newspapers on both sides of the Atlantic borrowed from each other: newspapers published in Boston picked up news from London, Paris, and Amsterdam; gazettes printed in Florence republished excerpts from Vienna, Madrid, and Philadelphia. However, the basic unit of news during this period was not, as in twentieth and twenty-first century newspapers, the article but the paragraph. Compared to other forms of writing, the paragraph could be easily separated out from one publication and inserted into another. The ease with which a paragraph could be reproduced and migrate facilitated the transmission of news across a growing network of periodicals at the end of the eighteenth century.

The American political leader John Adams provided an inside account of this phenomenon. During his diplomatic mission to France during the American Revolutionary War, Adams had access to a dozen French-language gazettes (including those printed in the Netherlands, the Rhineland, and Avignon) as well as English-language newspapers from London and several American cities. Reading through these periodicals, Adams was struck by the similarity of their accounts, and, in 1783, he warned the president of the American Congress.

The gazettes of Europe still continue to be employed as the great engines of fraud and imposture to the good people of America. Stockjobbers are not the only people who employ a set of scribblers to invent and publish falsehoods for their own peculiar purposes. British

This article was translated from the French by Michele Greer, revised by Will Slauter, and edited by Angela Krieger and Stephen Sawyer. 
and French, as well as other politicians, entertain these fabricators of paragraphs, who are stationed about in the various cities of Europe, and take up each other's productions in such a manner that no sooner does a paragraph appear in a French, Dutch or English paper, but it is immediately seized on and reprinted in all the others; this is not all: in looking over the American newspapers, I observe that nothing is seized on with so much avidity by the American nouvellists [sic] for republication in their gazettes as these political lies. I cannot attribute this to the credulity of the printers, who have generally more discernment than to be deceived. But I verily believe there are persons in every State employed to select out these things and get them reprinted. ${ }^{1}$

Adams worried that unfounded reports gained credibility as paragraphs traveled from one publication to another, and he was not alone. The writer, spy, and adventurer Ange Goudar noted that the interdependence of gazettes gave readers the illusion of a consensus about current events. "The States of Europe all agree," Goudar quipped. "Read the Gazette de Paris, the Postillion de Vienne, the Courrier d'Avignon, you will find the same lies repeated almost word for word." 2 False news, whether intentional or not, traveled quickly from one newspaper to another, and it was very difficult to stop its diffusion, as the London Craftsman remarked back in the 1730s. ${ }^{3}$ This problem had existed for a long time, but contemporaries noticed a new dimension with the appearance of the "paragraph writer" in the 1760s and 1770s. Readers became wary of this new type of hack writer, ready to sell his pen to defend political and financial interests. The Middlesex Journal of London mocked the paragraph writer for being half as expensive as an executioner but much more effective. Whereas an executioner charged 13 pence and a half per execution, "a paragraph writer shall kill you the stoutest man in the kingdom for his six-pence and bring him to life again for another." 4 A reader of the New York Daily Advertiser likewise observed that printers did not have time to write and were therefore duped by the "paragraphists." 5

These comments draw attention to a publishing phenomenon that was frequently noticed by contemporaries but remains little studied by historians: the rise of the paragraph as a genre of political writing and a vehicle for transmitting news. Far from being universal, the paragraph has a history that needs to be reconstructed in order to better understand how writing practices evolved in various fields, from

1. John Adams to Robert Livingston, 24 June 1783, in The Revolutionary Diplomatic Correspondence of the United States, vol. 2, ed. Francis Wharton (Washington: Government Printing Office, 1889), 503-4.

2. Ange Goudar, L'Espion français à Londres, ou Observations critiques sur l'Angleterre et sur les Anglois, par Mr. le chevalier de Goudar, ouvrage destiné à servir de suite à "l'Espion chinois" du même auteur, vol. 2 (London: 1779), 251-52.

3. Craftsman, July, 17, 1734, cited in Jeremy Black, "The British Press and Europe in the Early Eighteenth Century," in The Press in English Society from the Seventeenth to the Nineteenth Centuries, eds. Michael Harris and Alan J. Lee (Rutherford: Fairleigh Dickinson University Press, 1986), 65. 
philosophy and law to fiction and journalism. It was only at the end of the seventeenth century and the beginning of the eighteenth century that the division of printed texts into paragraphs became widespread; many books in the sixteenth and seventeenth centuries had few paragraph breaks or none at all. ${ }^{6}$ By contrast, it is difficult to imagine the novels, philosophical treatises, and printed constitutions of the eighteenth century without distinct paragraphs. The Age of Enlightenment was also the first great age of the paragraph.

In the case of journalism, the diverse ways in which the paragraph was employed (and contemporary attitudes toward these uses) reveal the specificity of the eighteenth century compared to other periods in the history of the press. By the early twentieth century newspaper articles were frequently composed of several paragraphs, the first of which ideally summarized the most important facts. ${ }^{7}$ The evolution of the journalistic paragraph over the course of the nineteenth century has yet to be studied. More recently, the different uses of the paragraph online, with "bloggers" replacing "paragraphists," merit closer examination. In the eighteenth century, newspapers and gazettes contained a wide range of texts, including official documents, excerpts from books, political essays, parliamentary debates, letters to the printer, poems, and advertisements. The paragraph, however, was the basic unit of political and military news, and the division of periodicals into distinct paragraphs facilitated the movement of news from one place to another.

The notion of the paragraph as a vehicle for news and a genre of writing in itself makes it possible to re-examine a classic subject-the circulation of texts in the revolutionary Atlantic World-by paying closer attention to contemporary publishing practice. ${ }^{8}$ Such a study builds upon a rich historiography of eighteenthcentury journalism in Europe, Great Britain, and North America. ${ }^{9}$ Though specialists

6. Henri-Jean Martin, La naissance du livre moderne. Mise en texte et mise en page du livre français (XIV'-XVII siècle) (Paris: Éditions du Cercle de la librairie, 2000), 317-26.

7. On the history of the lead paragraph, see Michael Schudson, The Power of News (Cambridge: Harvard University Press, 1995), 59-64. For more general information, see Kevin Barnhurst and John Nerone, The Form of News: A History (New York: Guilford Press, 2001).

8. Without discussing the paragraph, the first studies of Franco-American exchanges nonetheless demonstrated the importance of bibliographic analyses: Durand Echeverria, Mirage in the West: A History of the French Image of American Society to 1815 (Princeton: Princeton University Press, 1957); Robert Palmer, The Age of the Democratic Revolution: A Political History of Europe and America, 1760-1800 (Princeton: Princeton University Press, 1959-1965). For a more recent examination, see David Armitage, The Declaration of Independence: A Global History (Cambridge: Harvard University Press, 2007).

9. For an overview, see Hannah Barker and Simon Burrows, eds., Press, Politics and the Public Sphere in Europe and North America, 1760-1820 (Cambridge: Cambridge University Press, 2002). On the English-language press, see: Jeremy Black, The English Press in the Eighteenth Century (London: Croom Helm, 1987); Charles Clark, "Early American Journalism: News and Opinion in the Popular Press," in The Colonial Book in the Atlantic World, eds. Hugh Amory and David D. Hall (Chapel Hill: University of North Carolina Press, 2007), 347-66; and William B. Warner, "Communicating Liberty: The Newspapers of the British Empire as a Matrix for the American Revolution," English Literary History 72-2 (2005): 339-61. On the French-language press, see: Jeremy D. Popkin, Newes 
have observed that gazettes and newspapers of that era contained mostly foreign news, the way that news traveled across linguistic and political borders remains little studied. ${ }^{10}$ By following the movement of paragraphs from one periodical to another, it is possible to reconstruct the trajectory of news. The ongoing digitization of eighteenth-century periodicals facilitates this task by making it much easier to visualize how a single paragraph appeared in different publications. In order to better understand the role of the paragraph in the production and distribution of news, however, it is useful to develop insights from two disciplines concerned with the transmission of knowledge and the construction of meaning: the history of science and the history of books.

Highlighting the social roots of science and the role of error in the construction of knowledge, several studies in the history of science have shown how ostensibly universal facts were produced in specific contexts. ${ }^{11}$ Once scholars revealed the social, economic, and cultural conditions of "facts," they tried to understand, in Steven Shapin's words, "how to interpret the relationship between the local settings in which scientific knowledge is produced and the unique efficiency with which such knowledge seems to travel." 12 This problem became central to Adrian Johns, whose first monograph stood at the intersection of the history of printing and the history of science. Johns studied the circumstances of book production, distribution and reception "in order to show how print, like scientific truth, attains the level of universality-by the hard, continuous work of real people in real places." 13 Such an approach would be worth applying to the history of journalism. During the eighteenth century, each periodical was printed in a specific workshop. Once printed, it traveled to other workshops where it was combined with other written and printed sources to create new periodicals. When a report composed at a specific moment for a particular audience reappeared elsewhere, it was often

and Politics in the Age of Revolution: Jean Luzac's Gazette de Leyde (Ithaca: Cornell University Press, 1989); Jack R. Censer, The French Press in the Age of Enlightenment (London: Routledge, 1994); and Gilles Feyel, L'annonce et la nouvelle. La presse d'information en France sous l'Ancien Régime (1630-1788) (Oxford: Voltaire Foundation, 2000). Additionally, see the collective works cited throughout this article.

10. For recent studies in a similar vein, see: Ann Thomson, Simon Burrows, and Edmond Dziembowski, eds., Cultural Transfers: France and Britain in the Long Eighteenth Century (Oxford: Voltaire Foundation, 2010); Brendan Dooley, ed., The Dissemination of News and the Emergence of Contemporaneity in Early Modern Europe (Farnham: Ashgate, 2010). 11. Jan Golinski, Making Natural Knowledge: Constructivism and the History of Science (Cambridge: Cambridge University Press, 1998); Steven Shapin and Simon Schaffer, Leviathan and the Air-Pump: Hobbes, Boyle, and the Experimental Life (Princeton: Princeton University Press, 1985); Bruno Latour, Science in Action: How to Follow Scientists and Engineers Through Society (Cambridge: Harvard University Press, 1987); and Ken Alder, The Measure of All Things: The Seven-Year Odyssey and Hidden Error that Transformed the World (New York: Free Press, 2002).

12. Steven Shapin, "Here and Everywhere: Sociology of Scientific Knowledge," Annual Review of Sociology 21 (1995): 290. 
stripped of references to its origins. Scholars can reconstruct this process by following the movement of paragraphs from one periodical to another, being sure to note any editorial interventions (sometimes subtle or unintentional) that changed the meaning of the text.

To recover the work of the editors, translators, and printers involved in this process, this study also draws inspiration from the field of book history, especially the bibliographic studies of Donald McKenzie. McKenzie defined bibliography broadly as "the discipline that studies texts as recorded forms, and the processes of their transmission, including their production and reception." He examined texts in search of clues about how they were made, focusing on typography and layout, punctuation and spelling, and the use of indented lines and white space. ${ }^{14}$ McKenzie's method is perfectly suited to the study of periodicals because the comparison of slight differences between versions makes it possible to reconstruct the process of textual transmission. The addition or omission of a comma, for example, not only reveals the chain of evidence (who copied whom), but it also shows how practices of translation and rewriting transformed paragraphs as they circulated. Adapting McKenzie's methodology to news means highlighting not so much change over time (as he did by comparing editions of William Congreve from 1710 and 1946), but rather movement through space (by tracking a paragraph from, for example, the London Chronicle to the Gazette de la Martinique).

This article focuses on the circulation of news among French and Englishlanguage gazettes and includes a few Spanish examples. The links between German, Italian, Dutch, and Portuguese-language periodicals, among others, remain to be studied. After an outline of the rise of the paragraph as a tool for the circulation of news, the work of the editors who selected, translated, and rewrote paragraphs from elsewhere will be considered. Two examples from the American Revolutionary War will be used to illustrate the collective process that linked printers, editors, readers, and ship captains on both sides of the Atlantic. While confirming many of Adams's observations-the paragraph as the basic unit of news, London as the dominant source of information, and the interdependence of American and European newspapers-this study also emphasizes how the form and meaning of news changed as it traveled. Interdependence did not lead to uniformity: while the paragraph was a printed object that was easily reproduced, it was also a composite text ready to be revamped. 


\section{The Rise of the Paragraph as a Unit of News}

The paragraph is first and foremost a reading technology. The word comes from the Greek paragraphos and refers to an inscription made around a selected passage (either in the left-hand margin or below the line) to distinguish it from the surrounding text. The reader's inscription created a unit of meaning. As Hugh of St. Victor put it at the beginning of the twelfth century, "reading is dividing." 15 Over time this tool for reading also became a component of writing. With the help of the printing press, the paragraph went from being a sign inscribed in the margins to a distinct textual unit marked off by white space or indented lines. From the sixteenth century, paragraph breaks appeared in royal decrees as well as certain works of natural history and moral philosophy. According to Roger Laufer and HenriJean Martin, the use of paragraphs became much more widespread at the end of the seventeenth century and the beginning of the eighteenth century. ${ }^{16}$ While these scholars have noted the significance of paragraphs in philosophical texts and novels (where indentation was used to indicate dialogue), it should not be forgotten that newspapers were also important sites for the development of the paragraph. Furthermore, it was in their columns that the paragraph took on a new political role during the eighteenth century.

Periodicals devoted to recent events appeared almost simultaneously in several European cities in the early seventeenth century. The first printed papers, which contained bulletins from various cities and courts, drew upon scribal newsletters already in circulation. The first English corantos of the 1620s promised "faithful" translations of Dutch, German, Italian, and French periodicals. ${ }^{17}$ The French Gazette launched by Théophraste Renaudot in 1631 had access to the monarchy's diplomatic correspondence, but it also reproduced material from foreign periodicals. Similarly, the official London Gazette depended upon European newsletters and gazettes as well as consular dispatches. ${ }^{18}$ As Stéphane Haffemayer has suggested,

15. Roger Laufer, ed., La notion de paragraphe (Paris: Éd. du CNRS, 1985), 25; Malcolm B. Parkes, Pause and Effect: An Introduction to the History of Punctuation in the West (Berkeley: University of California Press, 1993).

16. Roger Laufer, "Les espaces du livre," in Histoire de l'édition française. Le livre triomphant, 1660-1830, eds. Henri-Jean Martin, Roger Chartier, and Jean-Pierre Vivet (Paris: Fayard, 1990), 156-72; Martin, La naissance du livre moderne, 317-26.

17. Brendan M. Dooley, The Social History of Skepticism: Experience and Doubt in Early Modern Culture (Baltimore: The Johns Hopkins University Press, 1999); François Moureau, ed., Répertoire des nouvelles à la main. Dictionnaire de la presse manuscrite clandestine XVI'XVIII siècle (Oxford: Voltaire Foundation, 1999); and C. John Sommerville, The Newes Revolution in England: Cultural Dynamics of Daily Information (Oxford: Oxford University Press, 1996), chap. 2.

18. Stéphane Haffemayer, L'information dans la France du XVII siècle. La Gazette de Renaudot de 1647 à 1663 (Paris: H. Champion, 2002), 17-18, 467-99; Peter Fraser, (Cambridge: Cambridge University Press, 1956), 4-5, 42-45. 
the circulation of gazettes across an expanding postal network during the seventeenth century contributed to "the birth of a European space of information." 19

In England, the lapse of the Licensing Act in 1695 put an end to prepublication censorship and encouraged the rapid growth of periodicals. Printers and editors began using the word paragraph to refer to short texts "copied from" or "inserted in" a particular newspaper. They indicated the source mainly in cases where they doubted the authenticity of the news. In 1696, for example, the London News-Letter accused the Flying Post of "forging a Paragraph from Vienna." The Flying Post referred its readers to the Dutch gazette from which it had translated the paragraph. But the London News-Letter insisted that copying from another paper did not excuse the editor of the Flying Post: if he had compared the Amsterdam gazette with that of Haarlem, he would have noticed that the "paragraph from Vienna" was a fake. ${ }^{20}$

With the proliferation of English and then American newspapers in the eighteenth century, "paragraph" became a common term among writers looking to get published in periodicals as well as among printers and editors. ${ }^{21}$ Each issue of a newspaper had a set number of pages containing a fixed number of columns. Filling these columns required juggling paragraphs: pieces of text had to be selected, edited, and combined to fit into the available space. ${ }^{22}$ A single column contained paragraphs on different subjects drawn from different sources, and these sometimes contradicted each other. In those cases, the paragraph break signaled rupture rather than continuity. Unlike in the scholastic tradition, where paragraphus (in Latin) indicated the next proposition in a line of argumentation, news paragraphs could be individual units of meaning. By liberating paragraphs from the text before and after them, eighteenth-century Anglo-American journalism created a new mode of writing. It became possible to submit a single paragraph to the newspaper. Some printers even set up mailboxes to receive manuscripts after hours so that good citizens could drop off their paragraphs anonymously. ${ }^{23}$

The Gazetteer and New Daily Advertiser, which had such a mailbox, announced its willingness to publish certain paragraphs paid for by the author, in the manner of advertisements. When a reader complained about a poorly written obituary in

19. Stéphane Haffemayer, "Transferts culturels dans la presse européenne au XVII siècle," Le Temps des Médias 11 (2008): 25.

20. London Newes-Letter, with Foreign and Domestic Occurrences, June 12-15, 1696, p. 1.

21. Michael Harris's study of the London press in the eighteenth century has confirmed that printers and political leaders often used the word "paragraph" to describe texts submitted to the printer or copied from other newspapers: Michael Harris, London Newespapers in the Age of Walpole: A Study of the Origins of the Modern English Press (Cranbury: Associated University Presses, 1987), 105, 122, 158-62, and 176.

22. An English daily like the Public Advertiser, which had four pages of four columns each, used six compositors to set the type. One of them, Richard Penny, explained in 1774 that he worked with his five colleagues "all together-all present-take different parts-some essays-some paragraphs," Add. 41,065, fols. 43-45, British Library.

23. Robert Haig, The Gazetteer, 1735-1797: A Study in the Eighteenth-Century English Newspaper (Carbondale: Southern Illinois University Press, 1960), 158; Hannah Barker, Newespapers, Politics, and Public Opinion in Late Eighteenth-Century England (Oxford: Oxford University Press, 1998), 39. 
1765, the editor replied: "that paragraph was inserted and paid for by a friend of the deceased; and we are no more accountable for the diction thereof, than for any other paragraph or advertisement which people pay to have inserted." 24 In the vocabulary of the time, letters were written to the printer, but paragraphs were inserted into a newspaper. The insertion of paragraphs was associated with intrigue and cunning, a perception reinforced by the fact that their authors remained anonymous. Readers therefore became suspicious of individual paragraphs that seemed designed to advance commercial or political interests. ${ }^{25}$

This politicization of the paragraph depended upon the development of a new "press infrastructure" in Britain during the 1760s, as John Brewer's work has shown. While supporters of John Wilkes used newspapers, pamphlets, and broadsides to spread political messages to an ever-increasing public, the Prime Minister Lord Bute employed his own paragraph writers. One of these writers for hire, John Campbell, described his work this way: "I have ... very carefully watched all the Inflammatory Paragraphs that have appeared in the Papers and have encountered them by other Paragraphs better founded as well as of a better tendency." 26 The paragraph thus became a literary genre adapted to political ends. Political leaders confronted each other through their intermediary paragraph writers, who were in turn ridiculed in the papers. The phrase "paragraph writer" began to appear in London newspapers in the 1760s and became much more frequent in the $1770 \mathrm{~s}$ before declining in subsequent decades. ${ }^{27}$ As an example, consider the satirical advertisement for a writing manual entitled The Complete Paragraph Writer, which was addressed to those who wanted to learn "the whole secret of contradicting, evading, misrepresenting, and confounding truth." 28 Although the paragraph writer was at first associated with exchanges between Wilkes and his opponents, the term came to refer to any author of slander, dubious news or unfounded claims. ${ }^{29}$

24. Gazetteer and New Daily Advertiser (London), March 13, 1765, p. 4, col. 1.

25. Lucyle T. Werkmeister, The London Daily Press, 1772-1792 (Lincoln: University of Nebraska Press, 1963), 7; Barker, Newspapers, Politics, and Public Opinion, 20-22, 68-70. 26. John Brewer, Party Ideology and Popular Politics at the Accession of George III (Cambridge: Cambridge University Press, 1976), 224; John Brewer, A Sentimental Murder: Love and Madness in the Eighteenth Century (New York: Harper Collins, 2004), 38-41.

27. A search of the Burney Collection of seventeenth- and eighteenth-century newspapers (housed by the British Library and digitized by Gale Cengage Learning) indicates that the term "paragraph writer" appeared in this collection (which is inevitably incomplete), once between 1740 and 1749 and never between 1750 and 1759. The expression appeared in six issues of various newspapers between 1760 and 1769, in eighty-seven issues between 1770 and 1779, in sixty-four issues between 1780 and 1789, and in forty issues between 1790 and 1799. Search performed January 28, 2011: http://gale.cengage. co.uk/product-highlights/history/17th--18th-century-burney-collection-newspapers-.aspx. 28. Morning Chronicle and London Advertiser, December 22, 1772, p. 2, cols. 1-2.

29. See, for example, London Evening Post: September 26, 1771; August 30, 1774; November 12, 1774; and March 17, 1778. Middlesex Journal: October 8, 1771; April 16, 1772; and April 18, 1772. Public Advertiser: November 17, 1772; July 3, 1773; and November 3, 1773. Morning Chronicle: May 11, 1773; December 6, 1773; December 25, 1773; January 2, 1775; April 4, 1776; June 26, 1776; and March 30, 1778. Morning Post: August 
According to some contemporaries, London had an army of these anonymous writers. Johann von Archenholz, a Prussian visitor to England, was struck by newspapers' reliance on "the paragraph writers, who go to the coffee-houses and public places to pick up anecdotes and the news of the day, which they reduce into short sentences, and are paid in proportion to their number and authenticity." 30 In another pamphlet from the era, the (anonymous) author advised readers not to be deceived by the "paragraphical drudges" who wandered the city gathering stories, which they turned over to writers who embellished them, transforming words recorded hastily in coffee shops into elegant and amusing paragraphs ready to be printed. ${ }^{31} \mathrm{~A}$ rare entry in an account book from the period confirms that these "paragraph makers" were sometimes paid. ${ }^{32}$ Nevertheless, many paragraphs were written by literary or political figures who did not expect financial compensation. ${ }^{33}$

The fact that readers were being warned about paragraph writers suggests that the paragraph was becoming a powerful weapon in the battle for public opinion. Indeed, it joined forces with other forms of publication, such as the pamphlet, the memoir, and the letter to the printer, each of which had its strengths. In 1785, the English politician Charles James Fox explained his strategy for the press: "Subjects of Importance should be first treated gravely in letters or pamphlets or best of all perhaps a series of letters, and afterwards the Paragraphs do very well as an accompaniment. It is not till a subject has been so much discussed as to become almost threadbare that Paragraphs which consist principally in allusions can be generally understood." 34

American cities did not have the same "press infrastructure" as London, but the colonial crisis of the 1760 s and 1770 s nevertheless generated a politicization of the paragraph. In Boston, for instance, the printing office of Benjamin Edes and John Gill became a kind of press agency where writers, lawyers, and political leaders gathered. One evening in 1769, John Adams participated in the collective preparation of the next day's Boston Gazette, which consisted of “[c]ooking up

31, 1776; March 8, 1777; and September 29, 1778. Gawetteer and New Daily Advertiser: March 14, 1776; May 13, 1778; May 16, 1778; June 2, 1778; October 17, 1778; and November 30, 1779.

30. Johann Wilhelm von Archenholz, A Picture of England Containing a Description of the Laws, Customs, and Manners of England ... (Dublin: P. Byrne, 1790), 42, cited by Barker, Newspapers, Politics, and Public Opinion, 49.

31. Literary Liberty Considered: In a Letter to Henry Sampson Woodfall (London: 1774), 16-17.

32. In the Gazetteer's account book, the entry for August 30, 1787 reads "paid for a paragraph,” 6 pence. C 104/68, vol. E, fol. 22, National Archives, Kew (PRO).

33. When the Earl of Sandwich sent a paragraph to the Public Advertiser in 1773, he spoke of himself in the third person, using the voice of an anonymous "paragraph writer": "We hear that the Earl of Sandwich has caused an action to be brought against the printer of the London Evening Post of the $2^{\text {nd }}$ of February, in order to vindicate his honour against the infamous falsehood contained in that paper." Sandwich to H. S. Woodfall, 3 February 1773, Add. 27, 780, fol. 21, British Library, London.

34. Cited in Barker, Newspapers, Politics, and Public Opinion, 44. 
Paragraphs, Articles, Occurrences, \& c.-working the political Engine!" 35 As relations between Great Britain and its North-American colonies deteriorated, Adams and his fellow Americans paid more and more attention to the circulation of paragraphs; words printed in Boston could have an enormous effect in London and vice versa. As Ian Steele's pioneering study showed, the arrival and departure of ships determined the rhythm of communication between the colonies and the mother country. Each ship brought newspapers filled with paragraphs ready to be copied, criticized, and contradicted. ${ }^{36}$

But the exchange was not limited to Great Britain and North America. The newspapers of Boston, Philadelphia, and Charleston depended on the London press for news from Rome, Berlin, and Amsterdam, and European gazettes drew a lot of material from English newspapers. In London, a growing number of papers (there were at least twenty-five during the 1780s) selected bulletins from various places and transformed them into paragraphs ready to be exported. The Courier de l'Europe, a French gazette printed in London, illustrated this process of importexport in a section called "Paragraphs Extracted from English Newspapers." 37 As Adams noted during his stay in Europe (first in France, then in Holland and England), the American Revolutionary War was a fruitful period for these exchanges. The war, which eventually involved France, Spain, the Dutch Republic, and several German principalities, rapidly expanded the readership of existing gazettes and encouraged the launching of new periodicals across Europe. ${ }^{38}$

Because European gazettes published a large amount of news from London during the American War, the English-style paragraph became familiar to readers on the continent. Editors of French-language gazettes were already wary of English newspapers, which were full of contradictory reports and debates between the ministerial party and the opposition. During the war, they began to see the "paragraph" as an English genre of writing that should be treated with suspicion. The editor of the Courier de l'Europe, based in London and aware of English journalistic

35. John Adams Diary, 3 September 1769, Adams Family Papers: An Electronic Archive, Massachusetts Historical Society, http://www.masshist.org/digitaladams/.

36. Ian K. Steele, The English Atlantic, 1675-1740: An Exploration of Communication and Community (Oxford: Oxford University Press, 1986).

37. For example, Courrier de l'Europe, January 7, 1783. On this gazette, see: Gunnar and Mavis von Proschwitz, Beaumarchais et le Courier de l'Europe. Documents inédits ou peu connus (Oxford: Voltaire Foundation, 1990); Simon Burrows, "The Courier de l'Europe as an Agent of Cultural Transfer (1776-1791)," in Ann Thomson, Simon Burrows, and Edmond Dziembowski, eds., Cultural Transfers: France and Britain in the Long Eighteenth Century (Oxford: Voltaire Foundation, 2010), 189-201.

38. Barker and Burrows, eds., Press, Politics and the Public Sphere; Horst Dippel, Germany and the American Revolution, 1770-1800: A Sociohistorical Investigation of Late EighteenthCentury Political Thinking (Chapel Hill: University of North Carolina Press, 1972; repr. 1977); Roland Krebs and Jean Moes, eds., La révolution américaine vue par les périodiques de langue allemande, 1773-1783 (Paris: Didier érudition, 1992); Franco Venturi, The End of the Old Regime in Europe, 1776-1789 (Princeton: Princeton University Press, 1991), vol. 1, chap. 1; and Elisabel Larriba, Le public de la presse en Espagne à la fin du XVIII siècle, 1781-1808 (Paris: H. Champion, 1998). 
practice, was careful to warn readers that "the [British] government and the opposition each have their own paragraph makers." 39

Whether based in London, Amsterdam, Paris or Avignon, the editors of French-language gazettes sought to impose order and coherence on the panoply of paragraphs printed in London. As Pierre Rétat and Myriam Yardeni have explained, European gazettes situated themselves between "events" and "history" by providing "raw material" to historians while offering "an initial sorting and synthesis of events." 40 Their editors did not hesitate to combine paragraphs from several English newspapers into a single bulletin (sometimes also called an "article") to which they added commentary on the credibility of reports. The form of the gazette, which organized the news as a series of bulletins from different cities, encouraged this practice. Meanwhile, the standard presentation of these bulletins (distinguished by date and place of origin) obscured the variety of sources that actually made up each issue. As Claude Labrosse and Pierre Rétat have explained, "Most [of each gazette] was made up of bulletins from the gazetteer's correspondents in the capitals and cities where the news was collected or of material that came from elsewhere or was copied from other gazettes but took on the appearance [of having come from correspondents]." 41 Although the bulletin was the most visible unit of European gazettes, the paragraph played an important role within each bulletin because it allowed the editor to juxtapose and combine news from various sources.

The interdependence of gazettes was such that even if no copy of the Gazeta de Madrid from September 24, 1784 ever reached New Hampshire, paragraphs from the same issue would nevertheless appear there indirectly: they would be translated into French by the Gazette de France, then translated into English by the Independent Chronicle in Boston, and finally copied by the New Hampshire Gawette. Similarly, paragraphs from a newspaper printed in Rhode Island would be copied in London, translated into French in Paris, and then retranslated into Spanish in Madrid. ${ }^{42}$ Printers sometimes specified the route of transmission, as in this example from a Boston newspaper: "The Brussels gazette, in an article from Paris, says, that a letter is come by the way of Leghorn, from an officer of the garrison of Pondicherry, dated the $10^{\text {th }}$ of November 1760." ${ }^{43}$ But most often the true sources of news became obscured as reports traveled from place to place. The Boston printer, for

39. Courier de l'Europe, October 22, 1776, p. 4, cols. 1-2.

40. Pierre Rétat, "Les gazettes. De l'événement à l'histoire," in Études sur la presse au XVIII ${ }^{e}$ siècle, eds. Henri Duranton et al. (Lyon: Centre d'études du XVIII ${ }^{\mathrm{e}}$ siècle de l'université de Lyon II, 1978), 3:37; Myriam Yardeni, “Journalisme et histoire contemporaine à l'époque de Bayle," History and Theory 12-2 (1973): 209.

41. Claude Labrosse and Pierre Rétat, "Le texte de la gazette," in Les gazettes européennes de langue française (XVII $-X V I I I^{e}$ siècle), eds. Henri Duranton et al. (Saint-Étienne: Publications de l'université de Saint-Étienne, 1992), 136.

42. First example: Independent Chronicle, January 2, 1783; New Hampshire Gazette, January 4, 1783. Second example: London Chronicle, November 11-13, 1777 and November 1518, 1777; Gazette de France, November 24, 1777; and Gazeta de Madrid, December 9, 1777. 43. Boston Post Boy, June 8, 1761, p. 2, col. 1. 
example, did not point out something that his readers had come to expect: he had copied the entire paragraph from an English newspaper and had never actually seen the "Brussels gazette" that he cited (see figure 1). ${ }^{44}$

Where did foreign news come from before the invention of the telegraph, satellite communications or the internet? By way of example, consider a paragraph published in the London Chronicle on October 15, 1776 under the heading Palma, the capital of Majorca, Sept. 3. It reported that forty-six prisoners attacked their guards near Algiers, seized a ship, and sailed to Palma, where they were now in quarantine. The source of the news was not, as might be expected, a letter sent from Palma to London, but a recycled paragraph. It was first printed in Spanish in the Gazeta de Madrid on September 17, then translated into French in the Gazette de Leyde and the Gazette d'Utrecht on October 11, before being retranslated into English in the London Chronicle four days later (see figure 2). ${ }^{45}$

Some editors took more liberties than others with the paragraphs they republished, as the following example illustrates. A paragraph from Cairo dated July 1, 1776 was first printed in the Gazette de France on October 14. Five days later, an abridged translation appeared in the London Chronicle. The bulletin's brief reference to English merchants must have been the point of interest, since the editor stopped translating beyond that section. The Courier de l'Europe copied the Gazette de France's version word for word, as did the Gazette d'Utrecht. The Gazeta de Madrid published the paragraph under the heading of Cairo, without mentioning that it had been translated from the Gazette de France. The Gazette de Leyde relied on the same source, but its editor added some sentences in which he condemned the Persians' brutality toward the inhabitants of Basra. This modification, which reveals the editor's stance, can only be detected by comparing different versions, because a paragraph printed in Paris and modified in Leiden was presented as having come from Cairo, where "by different letters" from Basra "we learn ..." (see figure 3). ${ }^{46}$

Such examples are far from exceptional: in most cases, foreign news did not come directly from correspondents belonging to the individual gazette, but from other periodicals. Gazettes had a shared convention of announcing paragraphs as coming from Palma or Cairo rather than specifying that they had been translated from Madrid or Paris. Editors did not necessarily seek to deceive their readers. Nonetheless, the organization of gazettes as a series of bulletins from different locations had the advantage of giving visual coherence to the news while avoiding

44. The same paragraph appears word for word on page 306 of the Public Ledger on March 31, 1761 and undoubtedly in other London newspapers.

45. Gazeta de Madrid, September 17, 1776, p. 335; Gasette d'Utrecht, supplement, October 11, 1776, p. 1; and London Chronicle, October 12-15, 1776, p. 366. The Utrecht version would later be copied by the Courier de l'Europe, October 18, 1776, p. 1, col. 3. Another French translation appeared in the Gazette de Leyde, supplement, October 11, 1776, p. 1. There were undoubtedly other versions.

46. Gazette de France, October 14, 1776, p. 375; London Chronicle, October 17-19, 1776 , p. 382; Courier de l'Europe, October 22, 1776, p. 1, col. 1; Gazette d'Utrecht, October 22, 1776, p. 1; Gazeta de Madrid, October 29, 1776, p. 377; and Gasette de Leyde, supplement, October 22, 1776, p. 1. 
Ronicrgatensen in Lower Hege, Spril $\mathrm{s}$.

HE. Allies continued to cantionade the works of
Calfel with greas vigour on the 27th. The

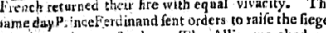
which twas done yeilerday. The Allies marched o of their Trenches with theír drums beating, afte taling down their heary cannon, to be clinbarked
for Hamelen. The toops marched by Fronhaufen and Diring has fen witho us being motelted in the lexit. Had the itege continued two days longer, the Fiench
wonld have been obliged to furreader tor want of pro wonld have been obliged to furreadcr tor want ot pro
vifiuns; but the check which the Allies fultained near Alaenheim, joined to the celerity of the march of the
French, did not allow them time to make an ond of French, did not allow therl tume to make an ond
the fiege. The two armies are again going into quatthe fiege. The two armies a $B E R L I N$, Marih 27.

其

HE. King's regiments ate almof all compleat,
and yet they continue to culitt men. His. - Majelty's army in Saxony will be feventy-five ther of forty thoufand men in silclia, which is defliced is thwart the projeds of the Ruffiens, who feem
diforfed w penetrate as carly as poffible into thas difpofed $w$ penetrate as carly as poffible into that
sutchy : and yct, if we may credit fome advices, the Nutchy : and yct, if we may credit nome advicesp the
fytem of thein court is a little wavering. Mr. Kcith, the Brition Miniller at Peserburgh, exerts his talents in fu th a mapner, as indaces us to think he docs not
lofe his tiane there : Some fay be has difparched an exprefs to his Coure with advice, :hiat the Ruffians will act but fainily, if the re gotiations for a peace, which
are faid to be on the tapis, clo not take a good turn are faid to be on the tapis, do not take a good turn
however this may be, we find they coine on very tatt however this may he, we hid mey co preparnious are

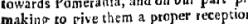

making to give them a proper reception.
LISE ON, March 10. The King is perfectly secovesed, and appears in Public as ufaal. His Majelty made lately a friall Military P'romotion. The Provincial Council will be heid here with all poffible Solem-
nity. All che Lands. Funds, and Effeets of the Jefuits are, by a Royall Fulict, confifcated to the Crown, fuch only exepted as are fatledio pious Ules. The Princefs of Brazil is fo faz advanced in her Pregn ancy, hit Ifandorgh. April 3 . According to advices received from Dantz ick, the Ruflians, who have beea
quantered, during the winter, in that neighbourhood,

now begin 10 draw nearer Pomelabia.
Hague, April 7. The Earl of ivembroke and Ld George Lenos have paffed thro' the Hague in their way to the army ; and Lieut. Gen. Conway is jult

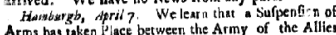
Arms has taken Place between the Army of the Allien and the French, for 6 Weeks; that the Convencion be. tween the IRuffians and Proffians is exrended to the fit
of Jaly; \& that notwithitanding the fufpention of $A$ ins of Jaly i \& that notwittitanding ine fufpenfion of Ating
is expired berween the Eruflians and Swedea, they con is expired berween the Pruflians and swedea, they con
tinue 10 live together in the moft friendly manner,

tinue to live together in the mort fricndly manner,

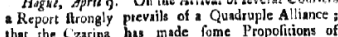
that the Crarina his made fome Propofitions of
Peace; and that asother pacificNegociation is upon the Carpet, unon which the Eng ifh Stocks have rifen on the 'Change et Amserdam furpritingly,

The Bruffels gazette, in an article from Paris, fays, that a letter is come by the way of Leghosn, the roth of Novepiber if 60 , imparing, "Tharthey hare forced the Englith 4 , raife the fiege of that place; and that as often as the Englih thall xcturn to the charge at Pondicherry, the iflue of their attempt will be always the fame.

Adague, Aprit a. The pacific rumours that for fome

time prevailed here, feem to fubficte apace.
The Marflal Prince de Soubife's Field Equipage arrived at Bruffelo ialt Sanday fe'mnight: it confilts of 27 Mules, 41 Sadtle Horles, three Coaties with a Set of Horfes 10 each,

- We have no Leteres from the Allied Atmy firce thofe of the zorn part. It the mean tirie we have various Reports concerting the late Mardics and Operattons of the firench Forees, fome of which ing port, that Maring raifed the siege of that Place, and had

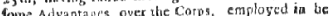
fieging it, upon their Reureat. from before cafiel on tic 27th; and prince Perdiand of Bunfwick had his Head Quarters in the Neightoushood of Frizhat the $2 g$ th

Hy Leters trom brublwick we are informed, that the Pritoners iaker by M.

$L O N$ D O N, March $2 \%$.

The Coif cans, incending to forne Ietters from Aeghorr, having rencived the hege of the cate of

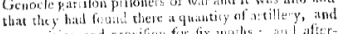

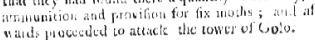

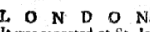
Marcb 28. It was reported at St. James's yefierday that the King of Sardinia $r$, d declared war. again On Tuef of Hungary. tate, of 30 Guns and 180 Mgmouth the Conece frigate, of $30 \mathrm{G}$ uns and $180 \mathrm{Men}$, taken by the Bed-
tord man of was, Cap.. Deane, who faw her tate into the sound and ftood out to Sea again.

The Comete was crufing at or near the mouth of Brittol Chatincl, in company with two French men war, one of 712 and gnother of 64 guns, who had ta
ken five prizes, and the 74 gun flip was gone with them to France.

Adiniraliy. Ofice, Marcb 27. His Majelty's Mip the Vengearce of 28 guns (nine and four pounders) an 200 men, commanded by Capt. Nightingale, is ar
rived at Ply mouth with two prizes ; one named the rived at Plymouth with two prizes; one named the
Entreprenaut, pierced for 44 , but now carrying only

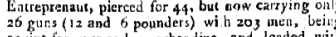
equipt for war and morchandize, and loaded wi Yarious kinds of goods for St. Domingo, witi which
the failed from Bourdeaux on the zt! intunt: 'The other a finath privateer of St. Maloes, carrying four carriage and four fiwivel guns, wich 45 mien, cont-
manded by Jofeph Merven, which the viageance feil in

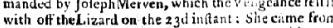
with oft the Lizard on the 23 dintant : Silt cetme for Captain Nightingale gives the following relatioa of lis engagement with the Entreprenans: That the got up clofe aloug. fide of her at five o'clock in the afterioon of the 13 th, when the attion immediately began, and continued for three quarters of an hour,
in which time the Vengeance was five times on fire in which time the Vengeance was five times on fire
(iwice, as was imagined, from the enemy's vads fetrigging and fails being then fo much Diatteres, that the thip was not under command, the euremy ran hi
the bowfprit over his tafferel for boarding: That he was therein grevented, and the Vengeance theer'd off, to
repair her rigging and fails. As foon as the Bip wa zepair her rigging and fails. As foon as the @ip was
in condition, Captain Nightingale got up again clofe in condition, Captain Nightingale got up again clof
to the enemy, when the engagement was renewed lor to the enemy, when the engagement was renewed lor away: That the Vengeance bring a fecond time difabled in her mafts and rigging, was fome time in
wearing : 'That at length the wore, and Captain
Nightingale got ag ain within piftol hot of the enemy. and renewed the engagement, which continurd an hour and a half, when the enemy called for quarter The Ven geance had fix killed and 27 wounded, mod

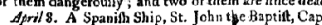
Capony, going from Haure-de-Grace for Cadiz, was
taken in the Year 1757 by an Englifh Man of War, the Cafe being lately brought before cneLords of $A p$ peal, they were plealed to difcharge the Ship, and co and Damapes.

\section{London, April r4.}

The King of Pruffia has granted M. de Hieer,
Swifs Olicer, Permifion to raile a free Company, Swifs Olicer, Permifion to raife a fice Company, to
be compofed only of Soldiers of his Nation, and of which he is to have the Command, with the Kank of Major. This new Troop is to affemble at Hall in Magdebourg, and it is expered it will be foon com-
plete, as the Swifs gives gret Encourtgement to his Couarrymen of good ligure, who offer.

According to Leters from Libbon, of the 5 th ult. a ine King of Portugal was hunting, he fell from hi Hand; upon which thar Court seturned very unexpectedly to than Metropolis from Salvateria.
By the Folus there is Advice, that a French Man By the Folus there is Advice, that a French Man
of War of 60 Guns, which came out of the Streights. of War of 60 Guns, which came out of the Streight and was bound to Miatinico, had

Saturday Morning a Fire broke out at Mr. Hart's,

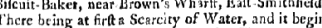
ning amongit old Timber. Houres, the Fll wines got to a great liead before the Engines could be ufed $;$ and
before it could be exringuifhed, it is faid 28 Hoof were bs routdown, and 12 ochers greatly damaged molt of the poor Inhitibitants, Who were working Peo fle, loolt their All, and with Dificulty faved thei
Lires. By a Party Wall falling belonging to the Hour oproutice the King'? Brewhoule, feveral Perfons were buried in the Ruins, but dug out alive; one hid lis Arm broke, ind onters mach lure, 'The King' Brewhoufe was preferv'd. The Fise was not extin-
guilhed till Six in the Evening. In the late Scarcity of Fuel, fome of the Thhabit nots
of Clostirf, went to the Noith Bull, to dig in the S.n s for cld Wrects, and in the Hold of a 3 hip (which fome of them recollected o hive been lon is ix Botles of very goout winc.

A new man of war of ninety guns is nearly compleated at Chathism ; the is to be cilled the Ocean. of the prefent mouth, and is the largen thip of that rate ever built in this kingdom.
Letter from J.itton fiyy, that the K.ing of Portugal has ified an edict for confifeitting, and uniting to $n$

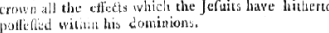

In the Houfe of Reprefentatives, Fune 5th. 1761

PHE Houle caking into Confiderarion his Ex
cellency's Mefliage of the firtt Inttant, and what may be proper for this Court furtherto do for the fpeedy raifing by Inliltment the three Court to be raifed for his Hajesty's Service on the fourth Day of April laft.

Voited, That the soldiers that have "been alrcady Inlitted and Muftered, fhall each receive the Surs of three Pound faupreas Sbillings and cigte Pence in ivioney, to all thofe who hlall hereafier Inlif, fhall at the Time of their paffing Multer receive a Bounty of Ninc Pound,
each; the feveral Bouaties to be paid to them by the Muifer Malter.

And furtber Voted, That the Cloathing to the

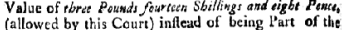
(allowed by this Court) infead of being Part of the $P$ art of thir $_{\text {W }}$ ages; and Stoppages be made fop Part of, their Wages; and Stoprages be made for
the fame upon the Mulier Rolls. And that the Inlift ment aforefaid continue
$\gamma_{\text {elly }}$ next, and no longer.

yely next, and no longer.
Sont af for Cencus

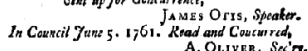
Conftured to FRA. BERNALD.

Fofepb \& uaniel $W$ aldo

In hiriz-lirect near the Court Houfe, Nituty thei

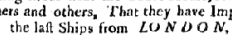

NAils of all Sorts, beft London

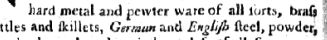
Aloot, lead, wool cards, window glals of all fizes. And in general a good affirmeat of HAKD WARBs, GLODO, a good aftortment of Euglifis and India widdss, oznabrigs, printed hineus, calicoes, linen \&
filk handkerchiets, cambricks and lawns, allopeens, Curoys, fagathy's, Getrutan ferges, haloons, durants,
tarnunys, ftrip'd camblets, calamancoes, broad rufiels $6 \cdot+$ clothes, thickfets, biack and white cyprus, wo men's velvet, taffatys, women's ltays, buckramb, chiefs, cotton laces, gartering, quatitys, nobais buttons, filk and mohair twift, black and colour' filk ritts, colour'd thread, firen and cotton checks cotton hollands, cotton gowns, dyed pillow, worliced caps, worlted and cotton hoffe, worfted brecehes
patterns, balladine feving filk, cord and braid, alk

ALL Perfons who have any

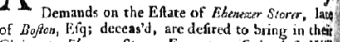
Clumis io Ethetezt Steres, Execuror of the latt Will of find Decens'd i and thofe who are indebted to vhe Jate Company of Elanezer Starer and Son, are defred
fpeedily to pay their refpedive Ballances to the fun viving Partoer, as they would avoid the Trouble of the Law. - And aid Stover hercby infornis the Caf the Lav. - And ard Stover hereby informis the Cuf
tomers of the late Company, that the fame Bufinel
will be carried on at the Store lately improved by will be carried on at the Store lately improved by
them. where he is now opening a compleat Affort ment of Goods JUST IMPORTED, fititable for th THIS is to GIVE NOTICE

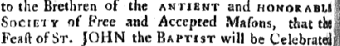
Feaft of Sr. JOHN the BArrusr will be Celebrated
by the Brethren of St. Andrew's Lodge, (helit by Aushority from the Right Hon. La:d Anez Dova,
Grand Matter of Circat-Eritain) on Wednefday ths Grand Matter of Creat-Erisain) on Wednciday that N. B. Tickets to be liad of Mrya Dojion and To be SOLD by JoHN WEBB, At his Warehoufe on the South. fide of the Town. Dock, Bolton,

CHoice Bait and Shipping Mackrit, Moluffes, Su. and Macketi Lines snd Hooks, Sal, \&e.

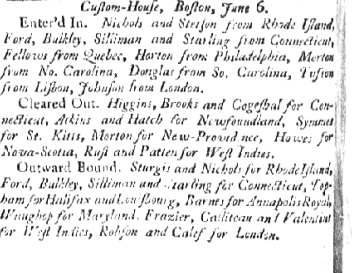

Figure 1. Green \& Russell's Boston Post-Boy \& Advertiser, June 8, 1761, p. 2, with a mix of paragraphs and advertisements typical of the American press during the colonial era. The paragraph referring to the Brussels Gazette appears in the first column between two paragraphs from The Hague. Image reproduced courtesy of Readex (NewsBank Inc.), Early American Newspapers Series I. 
Palma, Capital de la Isla de Mallorca, 3 de Setiembre. Quarenta y seis cautivos destinados á sacar piedra de unas canteras distantes algunas leguas al Poniente de Argél en un sitio llamado Génova, ansiosos de recobrar su libertad y resueltos á emprender qualquiera tentativa para ello, aprovecharon antes de ayer mañana de la ocasión de ver descuidados hácia la orilla del mar y con la escopetas en tierra á los 40 hombres de que se componía la guardia, que estaba para custodiarlos, atacaronlos valerosamente sirviendose de los mismos picos, palanquetas y demas herramientas de su trabajo, lograron apoderarse de sus armas, y matando á 33 Moros que querian resistirse igualmente que á 11 marineros de 13 que había en el lanchon que servía para acarrear á la Plaza la piedra que ellos sacaban, y obligando á los otros dos á echarse al mar se hicieron dueños de dicho barco. Libres ya, y provistos con 12 fusiles, 2 pistolas, otros tantos trabucos, y 12 taxanes que cogieron en las dos refriegas, se hecharon á navegar, habiendo tenido la fortuna de aportar aquí hoy de madrugada; donde quedan haciendo quarentena en el Lazareto. Entre estos esclavos había 16 Españoles, 17 Franceses, 8 Portugueses, 3 Italianos, un Aleman y un Sardo; todos muy contentos por el feliz exito de su arrojo.

Gasette d'Utrecht, 11 octobre 1776

De PALMA, Capitale de l'Isle de Majorque, le 3 Septembre. Quarante-six captifs destinés à tirer des pierres d'une carrière, située à quelques lieues d'Alger dans un endroit nommé Genova, désirant de recouvrer leur liberté, \& résolus de tenter fortune, profitèrent hier de l'inaction des 40 hommes qui composoient leur garde \& qui étaient oisifs au bord de le mer, après avoir mis leurs mousquets à terre. Ils les attaquèrent hardiment à coups de pics \& autres ustensiles de fer, \& parvinrent à se rendre maîtres de leurs armes, \& ayant tué 33 Maures qui vouloient résister, ainsi que onze des treize mariniers qui étoient dans le bâteau qui servoit à transporter les pierres, ils forcerent le reste à se jetter dans la mer. Alors maîtres du bateau \& armés de douze fusils, de deux pistolets, $\&$ de cartouches, ils se mirent à naviguer, \& ont eu le bonheur d'aborder ici ce matin, où ils font la quarantaine au Lazareth. Parmi ces esclaves, il y a 16 Espagnols, 17 François, 8 Portugais, 3 Italiens, 1 Allemand et 1 Sarde, qui sont tous bien contens de leur réussite.
De PALMA, Capitale de l'Isle de MAJORQUE, le 3 Septembre. Quarante-six Captifs, employés à tirer des pierres d'une Carrière située à quelques lieuës d'Alger, dans un endroit nommé Genova, formèrent le dessein de recouvrer leur liberté; $\&$ résolus de tenter fortune ils profitèrent hier de l'inaction des 40. Maures, qui composoient leur garde, \& qui, après avoir posé leurs mousquets à terre, étoient tranquilles \& oisifs sur le bord de la Mer: Ils les attaquèrent à coups de pics \& d'autres instrumens de fer: \&, étant parvenus à se rendre maîtres de leurs armes, ils tuèrent 33 . de ces Maures, qui voulurent leur résister, ainsi que onze des treize Mariniers, qui étoient dans le Bâteau, lequel servoit à transporter les pierres; \& ils forcèrent les deux autres à se jetter à la Mer. Alors maîtres de ce petit Bâtiment, armés de douze fusils, de deux pistolets, \& de cartouches, ils prirent le large ; \& ce matin ils ont eu le bonheur d'aborder en cette Rade, où ils font quarantaine au Lazaret. Le nombre de ces Fugitifs, tous trèscontens de la réussite de leur entreprise hardie, consiste en 16 Espagnols, 17 François, 8 Portugais, 3 Italiens, 1 Sarde, \& un Allemand.

\section{London Chronicle, 12-15 October 1776}

\section{Palma, the Capital of Majorca, Sept. 3}

Forty-six captives who were employed to draw stones from a quarry at some leagues distance from Algiers, at a place named Genova, resolved, if possible, to recover their liberty, and yesterday took advantage of the idleness and inattention of 40 men who were to guard them, and who had laid down their arms and were rambling about the shore. The captives attacked them with pickaxes and other tools, and made themselves masters of their arms, and having killed 33 of the 40, and 11 of the 13 sailors who were in the boat which carried the stones, they obliged the rest to jump into the sea. Being then masters of the boat, and armed with 12 muskets, two pistols, and powder, \&c. they set sail, and had the good fortune to arrive here this morning, where they are performing quarantine. Sixteen of them are Spaniards, 17 French, eight Portuguese, three Italians, one German, and one Sardinian.

Figure 2. Four versions of a paragraph from the Palma. 
Gazette de France, 14 octobre 1776

Du Caire, le $1^{\text {er }}$ Juillet 1776

On apprend par diverses lettres de Bassora que les Persans exigent des malheureux Habitans de cette Ville une contribution de 125,000 tomans (le toman est évalué 95 l. de France environ); sçavoir, de la part des Turcs, 100,000, \& 25,000 de la part des Chrétiens, Juifs, \& Commerçans Arméniens. On offre à Sader Kan, frere de Kerim Kan, le tiers de cette somme exorbitante, dont on ne peut donner qu'un dixieme en especes, \& le reste en marchandises. Ces lettres ajoutent que le Commandant des Persans a fait mourir sous le bâton quarante personnes qu'on soupçonnoit de s'être refusées à la contribution; que le fils de Chek Dervich, celui d'un riche Négociant Turc \& deux Négocians Arméniens, ont été députés vers Kerim Kan; que les Anglois sont revenus s'établir dans cette Ville, et qu'ils n'éprouvent, ainsi que les autres Européens, aucune vexation; qu'on y attend avec impatience la décision de Kerim Kan sur le sort de la Ville et des Habitans; enfin qu'ils n'ont aucune relation directe ou indirecte avec Bagdad \& les autres Villes de la Syrie, \& qu'ils s'adressent aux Habitans de la Ville d'Alep pour en apprendre des nouvelles.

Le Pacha de cette derniere Ville gouverne toujours avec la plus grande modération; mais le commerce languit par le défaut de circulation des caravanes, causé par les troubles de Bagdad \& de toute la Côte de la Syrie.

\section{London Chronicle, 17-19 October 1776}

Saturday, Oct. 19.

Yesterday arrived the Mails from FRANCE, HOLLAND, and FLANDERS. Cairo, July 1.

By several accounts from Bassora we hear, that the Persians demand a contribution of 125,000 tomans from the unhappy inhabitants of that city, viz. 100,000 from the Turks, and 25,000 from the Christians, Jews, and Armenian Merchants. They have offered Sader Kan, brother to Kerim Kan, one third of that exorbitant demand, to be paid one tenth in specie, and the rest in merchandize. These accounts add, that the Persian Commander caused 40 persons to be beaten to death, whom he suspected of being against the contribution; that the son of Chick Dervich and one of a rich Turkish Merchant, with two Armenian Merchants, were deputed to Kerim Kan. The English have returned to that city, and are not in the least ill treated, any more than any of the Europeans.
Gazette de Leyde, 22 octobre 1776

DU CAIRE, le 1. Juillet. La conduite modérée, que les Persans paroissoient vouloir tenir à Bassora, après la prise de cette Ville, ne s'est point soutenuë. On a appris par différentes Lettres, qu'ils ont exigé des malheureux Habitans une Contribution de 125. mille Tomans; (le Toman est évalué à environ 95. Livres de France) savoir de la part des Turcs, 100. mille; de la part des Chrétiens, Juifs, \& Commerçans Arméniens 25. mille. On avoit offert à Sader-Kan le tiers de cette Somme exorbitante, dont on ne pouvoit même donner qu'un dixième en Espèces, \& le reste en Marchandises; mais ce Commandant, loin de se laisser flêchir par l'impuissance de ces infortunés, et par la misère où ils se trouvent réduits après un Siège aussi long que rude, avoit fait mourir sous le bâton quarante personnes, qu'il soupçonnoit de s'être refusées à la Contribution. Cependant le Fils du Cheïk Dervich, celui d'un riche Négociant Turc \& deux Négocians Arméniens, avoient été députés vers son Frère Kerim-Kan, Régent de Perse, pour implorer sa miséricorde; \& l'on attendoit avec impatience la décision de ce Prince sur le sort de la Ville \& de ses Habitans. On apprend par les mêmes Lettres, que les Anglois, qui avoient quitté Bassora à l'ouverture du Siège, sont revenus s'y établir, et qu'ils n'éprouvent, ainsi que les autres Européens, aucune vexation. Au reste la Ville n'avoit aucune relation directe ou indirecte avec Bagdad \& les autres Villes de la Syrie, \& elle s'adressoit aux Habitans d'Alep pour en apprendre des Nouvelles. Le Pacha de cette dernière Ville gouverne toujours avec la plus grande modération; mais le Commerce y languit par le défaut de circulation des Caravanes, causé par les troubles de Bagdad \& de toute la Côte de la Syrie.

\section{Gazeta de Madrid, 29 de Octubre de 1776}

El Cairo á $1^{\circ}$ de Julio. Por cartas de Bassora se sabe, que los Persas exîgen de los infelices habitantes de aquella Ciudad una contribucion de 125000 tomanes*; $^{*}$ es á saber 100000 de los Turcos, y lo restante de los Cristianos, Judios, y traficantes Armenios; y que efectivamente ya le ofrecen á Sader Kan hermano de Kerim Kan la $3^{\text {a }}$ parte de tan exorbitante suma, bien que solo le pueden aprontar en dinero la decima, y lo restante en mercaderías. Añaden dichos avisos, que el Comandante Persa ha hecho quitar la vida á palos á 40 sugetos, que sospechó se oponian al pago de aquella cantidad; que los sitiados enviaron Diputados á tratar con Kerim, cuya decision se aguardaba con impaciencia; que los Ingléses habían vuelto á establecerse en la Ciudad, donde ni ellos ni los demás Européos experimentan vexacion alguna; finalmente que estaba interrumpida toda comunicacion con Bagdad y con las otras Plazas de Siria, siendoles forzoso recurrir á los de Alepo para tener por su conducto las noticias.

(*) Cada toman vale 25. pesos.

Figure 3. Four versions of a paragraph from the Cairo (modifications by the Leiden editor in bold). 
the clutter that would have resulted from making the source of each paragraph explicit. Moreover, the canonical form of the gazette provided a way of organizing space and time. As Denis Reynaud has suggested, "the division of the gazette into clearly labeled geopolitical sections was not a mere editorial convenience, but the gazetteer's primary means of asserting a political vision while maintaining the appearance of unshakeable neutrality." 47

Correspondents were obviously necessary for procuring news from places that had no printed gazettes or scribal newsletters and for learning about subjects likely to be censored. French-language gazettes often had a correspondent in Paris to provide news not printed in the Gazette de France. ${ }^{48}$ However, the most important manuscript sources were not correspondents but other publications, such as the Parisian nouvelles à la main and the Venetian avvisi, which had been circulating since the seventeenth century. ${ }^{49}$ Samuel Swinton, the owner of the Courier de l'Europe, pressured his editor in Maastricht (where Swinton launched a publication similar to the Courier) to reproduce the contents of a Paris-based newsletter for his colleagues in Cologne, Amsterdam, Utrecht or Leiden because he knew they all relied on the same source. ${ }^{50}$ According to François Moureau, these "mobile manuscripts" were at the heart of the information system of the Old Regime: "in the absence of news agencies, the printed gazettes fed off the nouvelles à la main, which circulated internationally." Cities where the gazettes were printed, such as Paris, Rome, and Cologne, "served as transit points for scribal 'papers,' which after being translated, adapted, revised, and contaminated, would continue on their journey: the circuit was self-generating." 51

The proliferation of printed gazettes in the second half of the eighteenth century led to the creation of digests such as the Gazette des Gazettes and the Journal des Journaux. When Charles Joseph Panckoucke launched the Journal historique et politique (dubbed the Journal de Genève) in 1772, he promised to make it a synthesis of all the European gazettes. Several people were employed to translate paragraphs from English, Swedish, Danish, Russian, Dutch, and German papers. ${ }^{52}$ The official

47. Denis Reynaud, "La politique des rubriques," in La Gazette d'Amsterdam. Miroir de l'Europe au XVIII siècle, ed. Pierre Rétat (Oxford: Voltaire Foundation, 2001), 22330. Additionally, see Censer, The French Press in the Age of Enlightenment, 17-19.

48. François Moureau, "Les Mémoires Secrets de Bachaumont, Le Courier du Bas-Rhin et les 'Bulletinistes' parisiens," in L'année 1768 à travers la presse traitée par ordinateur, eds. Jean Varloot and Paule Jansen (Paris: Éd. du CNRS, 1981), 58-79; Popkin, News and Politics, 73-74.

49. Mario Infelise, "Le marché des informations à Venise au XVII' siècle," in Gazettes et information politique sous l'Ancien Régime, eds. Henri Duranton et Pierre Rétat (SaintÉtienne: Publications de l'Université de Saint-Étienne, 1999), 117-128; Filippo de Vivo, "Paolo Sarpi and the Uses of Information in Seventeenth-Century Venice," in News Networks in Seventeenth-Century Britain and Europe, ed. Joad Raymond (London: Routledge, 2006), 35-50.

50. Swinton to Launay, London, 10 May 1780, ms. 12451, fols. 212-213v, Bibliothèque de l'Arsenal, Paris.

51. François Moureau, La plume et le plomb. Espaces de l'imprimé et du manuscrit au siècle 
gazettes of London, Paris, and Madrid, which each benefitted from access to diplomatic dispatches, became important sources for other periodicals. Yet these three gazettes also depended upon scribal and printed publications. ${ }^{53}$ In 1778 , for example, the Gazeta de Madrid (which mostly relied on French sources) subscribed to eight different periodicals published in Paris. Subscriptions were expensive and editors had an incentive to exchange papers, which the editor of the Madrid gazette did with his counterparts in Paris and Brussels. ${ }^{54}$

Even in the Anglo-American press, original texts were much less numerous than paragraphs copied from other newspapers. An analysis of the Pennsylvania Gazette conducted by Charles Clark and Charles Wetherell revealed that at least two-thirds of the texts (paragraphs, letters, and essays combined) that appeared in that gazette during the colonial period were taken from other periodicals. Only one text out of ten came from a correspondent. ${ }^{55}$ During the early republic, and especially during the 1790s, American newspapers changed tone and their editors played an overtly political role, many of them aligning with the "Federalists" or the "Republicans." ${ }^{56}$ But the paragraph remained crucial because the influence of political parties at the national level depended on the dissemination of their messages across geographic space. Each side reprinted and criticized the words of the other side's "paragraphists." 57 The Post Office Act of 1792 gave American printers the right to send a copy of their newspapers to all other printers in the country postage free. This policy dramatically increased the number of newspapers available to editors, who skimmed them looking for paragraphs to republish in a new form, often with the help of scissors and paste. ${ }^{58}$ But interdependence did not mean standardization. Unlike a centralized system in which an identical newspaper was distributed everywhere, the "free exchange" of newspapers allowed each printer to select paragraphs from elsewhere and adapt them to his local public. ${ }^{59}$

53. Fraser, The Intelligence of the Secretaries of State, 36-46 and 52; Haffemayer, L'information dans la France du XVII' siècle, 154-55 and 484-85; and Feyel, L'annonce et la nouvelle, 886 .

54. Luis Miguel Enciso Recio, La Gaceta de Madrid y el Mercurio histórico y político, 17561781 (Valladolid: Universidad de Valladolid, 1957), 33.

55. Charles Clark and Charles Wetherell, "The Measure of Maturity: The Pennsylvania Gazette, 1728-1765," The William \& Mary Quarterly 46-2 (1989): 294-97.

56. Marcus Daniel, Scandal \& Civility: Journalism and the Birth of American Democracy (Oxford: Oxford University Press, 2009).

57. See, for example, the paragraph "From the National Gazette" found in the Gazette of the United States, April 18, 1792, p. 407.

58. Richard Kielbowicz, News in the Mail: The Press, Post Office, and Public Information, 1700-1860s (Westport: Greenwood Press, 1989); Richard John, Spreading the News: The American Postal System from Franklin to Morse (Cambridge: Harvard University Press, 1995); and Charles Steffen, "Newspapers for Free: The Economies of Newspaper Circulation in the Early Republic," Journal of the Early Republic 23-3 (2003): 381-419.

59. David Waldstreicher, In the Midst of Perpetual Fetes: The Making of American Nationalism, 1776-1820 (Chapel Hill: University of North Carolina Press, 1997), 18, 34, and 10910; Jeffrey Pasley, "The Tyranny of Printers": Newspaper Politics in the Early American Republic (Charlottesville: University of Virginia Press, 2001), 49-50, 173-74, 208, and 330-31. 
Adams was not alone in worrying about how the London press influenced news published elsewhere. During the American Revolutionary War, he and his colleague Benjamin Franklin responded to English reports by sending news to editors in Dutch cities, thus becoming the official "paragraph writers" of the Thirteen Colonies. ${ }^{60}$ Franklin even forged an entire issue of the Boston Independent Chronicle at his press in Passy. Hoping to expose the British army's cruelty before the European public, Franklin sent his false gazette to Amsterdam and The Hague, and excerpts of it eventually appeared in London. ${ }^{61}$ The American delegates also worked with Edmé-Jacques Genet, head of the interpreters bureau in Versailles and editor of the Affaires de l'Angleterre et de l'Amérique, a periodical published by the French Ministry of Foreign Affairs. Genet drew paragraphs from the London press and reworked them so as to emphasize British weaknesses and thereby support the American cause. ${ }^{62}$

Genet (whose son would become the notorious "Citizen Genet") proposed an original idea for strengthening Franco-American relations through the press. He would print an English-language newspaper in Paris and then distribute copies through American printers, who could also "reprint, comment, respond, etc., and thereby increase their readers' curiosity." 63 'This project was not realized, but some French-language gazettes with a similar goal to neutralize British influence on American public opinion did appear in America during the 1780s and 1790s. In 1789, the Courier de Boston complained about "the plots of speculators and English gazetteers" and boasted of "freeing the confederated Americans from the kind of moral slavery in which they continue to suffer by means of the English public papers, the sole source from which they draw all their opinions." 64 The Philadelphia-based Courier de l'Amérique also emphasized the need for Americans to free themselves from the London press and obtain information directly from European periodicals like the Gazette de Leyde. ${ }^{65}$ This gazette was also Thomas Jefferson's favorite, and he urged the editors of various American newspapers to translate excerpts from it. ${ }^{66}$ Despite such efforts, the London press remained, in the words of Adams, "an engine by which everything is scattered all over the world." 67 The efficiency of that "engine" depended in part on the mobility of the paragraph, a typographical unit ready to be reproduced and commented upon by newspapers in Dublin, Philadelphia, Halifax, and Kingston, Jamaica.

60. Peter Ascoli, "American Propaganda in the French Language Press During the American Revolution," in La révolution américaine et l'Europe, eds. Glaude Fohlen and Jacques Godechot (Paris: Éd. du CNRS, 1979), 291-305.

61. Ellen Cohn et al., eds., The Papers of Benjamin Franklin (New Haven: Yale University Press, 1959-2011), 37:184-97, 205-7, and 268.

62. Madeleine Fabre, "Affaires de l'Angleterre et de l'Amérique," in Dictionnaire des journaux, 1600-1789, ed. Jean Sgard (Oxford: Voltaire Foundation, 1991), 1:5-10.

63. Cohn et al., eds., The Papers of Benjamin Franklin, 27:155-56.

64. Cited in Alain Nabarra, "Courier de Boston," in Dictionnaire des journaux, 1600-1789, ed. Jean Sgard (Oxford: Voltaire Foundation, 1991), 1:275-77.

65. Courrier de l'Amérique, December 4, 1792.

66. Pasley, "The Tyranny of Printers," 61-63; Daniel, Scandal \& Civility, 45-48.

67. John Adams to the President of Congress, Paris, 8 September 1783, in The Revolution- 


\section{Editorial Work: "Cutting and Pasting" Paragraphs}

In a world where newspapers were made up of excerpts from other newspapers, scissors and paste were essential tools for editors. As Ann Blair and others have shown, the "cut and paste" function in word processing software shares in a long history of reading and writing going back to the Renaissance. To save time and facilitate compilation, the sixteenth-century scholars Conrad Gesner and Girolamo Cardano advised cutting texts with scissors and rearranging the pieces as needed. Nevertheless, when the editor of the first edition of the Encyclopedia Britannica (1768-1771) quipped that he had "made a Dictionary of Arts and Sciences with a pair of scissors," he suggested how this practice could seem demeaning to those who preferred to present themselves as writers rather than artisans. ${ }^{68}$ The same tension appeared in the political press. In 1790, a reader visited the workshop of Benjamin Franklin Bache, grandson of Benjamin Franklin and printer of the Philadelphia General Advertiser. According to this reader, Bache had an ink well and a pen but did not use either, preferring to rely on "a large pair of taylors' shears." Surrounded by newspapers, "you cut out of other papers as much [text] as you thought would fill yours." When the shop assistant arrived asking for more "copy" (a term for the manuscript or printed text to be reproduced), the editor leafed through his newspapers to find the right amount and cut it out on the spot. ${ }^{69}$

This description of editorial work is a caricature. Nevertheless, it reveals how clipping from existing newspapers made an editor's job easier: by examining a printed page, he could count the number of lines for each paragraph, select the paragraphs that would fill his own columns and arrange them in a collage. More generally, it was easier for printers to work from a printed version of a text than from a written one, which required deciphering the handwriting, correcting the grammar, and counting the words that would fit on each line. Although the work of composition (or typesetting) still had to be done by hand, part of the work involving correcting and line justification had already been done by the printer of the newspaper being copied. ${ }^{70}$

The paragraph facilitated the reprinting of news, but conceptions of literary property and plagiarism were evolving during this period and some editors began to demand "credit" for borrowed texts. ${ }^{71}$ Yet practices of citation remained inconsistent.

68. Ann Blair, "Reading Strategies for Coping with Information Overload ca. 15501700," Journal of the History of Ideas 64-1 (2003): 27.

69. General Advertiser, October 25, 1790, cited by Daniel, Scandal \& Civility, 117.

70. On composition, see Philip Gaskell, A New Introduction to Bibliography (New Castle: Oak Knoll Press, 2006), 40-56; Jacques Rychner, "Le travail de l'atelier," Histoire de l'édition française. Le livre triomphant, 1660-1830, eds. Henri-Jean Martin, Roger Chartier, and Jean-Pierre Vivet (Paris: Fayard, 1990), 46-70.

71. Journalistic plagiarism was noticed by French readers as well. In 1777, for example, a reader accused the Journal historique et politique of having copied the Courier de l'Europe "word for word" without any reference. "Among you Journalists, plagiarism is to a certain extent the norm, and I would not have the slightest objection if it were exercised 
In 1805, the editor of the Philadelphia Evening Post attacked "scissors editors" who stole the work of others. "When ... a man takes his scissors and cuts out my article, and gives it to the world as his own, he derives an unfair advantage from my productions, and multiplies his subscribers at my expense." According to him, editors who thought that they could avoid plagiarism by indicating the name of the city at the top of a column of paragraphs were wrong because "to quote a political paragraph with 'Philadelphia paper' at the head or tail of it, when there are seven or eight papers printed in this city, is a mean and despicable way of pilfering." 72 Grouping together paragraphs by place of origin was coming to seem obsolete, and some readers began calling for a presentation of news according to its importance, with a clearer separation between each "article." 73 However, such changes were not yet implemented, and the expression "scissors editors" referred to a practice that continued up to the mid-nineteenth century and beyond. ${ }^{74}$

\section{Newspapers as Collective Works}

Behind the layout of newspapers lies the work of the editors who copied, translated, and modified paragraphs. Two events from the American Revolutionary War perfectly illustrate the collective process that was transatlantic journalism in the eighteenth century: the defeat of George Washington at Brandywine, Pennsylvania and the surrender of John Burgoyne's army at Saratoga, New York. These two events took place in the fall of 1777: in September, the British victory at Brandywine opened the way for the capture of Philadelphia, at that time the capital of the United States. Further north in Saratoga, American forces surrounded General Burgoyne, causing him to surrender his entire army on October 17, 1777. The events are well known, but the surprising way in which they were reported merits study. The first European reports of Burgoyne's surrender, though based on American sources, were false. By contrast, the first news of Washington's defeat, though accurate, was not considered authentic in Europe. In both cases, the interpretation of events can be explained by the way the form and content of the news evolved as it traveled from one place to another.

in good faith; but why this affectation to reprint your Gazette under the title Journal, and then give excerpts of all that seems worth collecting from the foreign Gazettes without mentioning the Courier de l'Europe!" See Courier de l'Europe July 18, 1777, pp. 111-12. For general information on plagiarism, see: Adrian Johns, "The Ambivalence of Authorship in Early Modern Natural Philosophy," in Scientific Authorship: Credit and Intellectual Property in Science, eds. Mario Biagioli and Peter Galison (New York: Routledge, 2003), 68-90; Paulina Kewes, ed., Plagiarism in Early Modern England (New York: Palgrave Macmillan, 2003).

72. Evening Post, copied by Aurora General Advertiser, January 19, 1805, p. 2.

73. See Pasley, "The Tyranny of Printers," 32.

74. On April 27, 1901, the San Jose Mercury News republished the following small paragraph, citing the Chicago News: “'Credit to whom credit is due,' is an old saying that the scissors editor frequently overlooks." 
Consider first Burgoyne's defeat. The news reached the French port of Lorient on October 6, 1777, eleven days before Burgoyne surrendered to General Horatio Gates at Saratoga. The origin of the report was Captain Thomas Thompson, who had just arrived from America. The day of his departure, Thompson passed in front of another ship in Boston Bay. The other ship's captain had heard that General Burgoyne and his guards had been surprised and overtaken. Thompson remained skeptical about this report, but another American captain who arrived in Lorient the same day had also heard about a major defeat. According to the latter, the Americans had 2,500 British soldiers and taken six hundred of them prisoner during various battles. ${ }^{75}$

The oral news of the two captains was transcribed, embellished, and circulated across Europe. An excerpt of a letter from Lorient published in the Courier $d u$ Bas-Rhin reported that the Marquis de la Fayette, at the head of two thousand and five hundred, attacked a group of two thousand British, capturing six hundred and killing the rest. ${ }^{76} \mathrm{~A}$ paragraph from Bordeaux printed in the Courrier d'Avignon claimed that it was not Lafayette but the Generals Benedict Arnold and Arthur St. Clair who attacked the British army at Fort Edward and seized General Burgoyne. Two weeks later, this issue of the Courrier d'Avignon arrived in London, and the paragraph was translated into the Morning Chronicle, which was copied in turn by other English newspapers. ${ }^{77}$ The great "engine" that was the London press then circulated the following paragraph attributed to the Kentish Gasette:

We are informed by Letters which arrived last Week in the Transports from Quebec, that Burgoyne and his Army, after being several Days surrounded by the Generals Arnold and Conway with 12,000 Men ... surrendered Prisoners of War on the $4^{\text {th }}$ of October last.

An editorial remark advised readers to "give what Gredit they think due to the above Accounts" but promised that the same source had been reliable in the past. The Public Advertiser took this whole paragraph from the Kentish Gazette, including the editorial warning. The London Evening Post copied the version in the Public Advertiser but omitted the comment about the credibility of the news. ${ }^{78}$ The Gazette de France, for its part, translated the paragraph found in the London Evening Post but thinly veiled Lafayette's name. In Paris, Avignon, and Madrid, periodicals reproduced the same paragraph citing letters from Quebec, but in reality their versions all came from the Gazette de France. ${ }^{79}$

75. Papers of Benjamin Franklin, 25:59.

76. Courier du Bas-Rhin, October 29, 1777, p. 707 and November 1, 1777, pp. 715-16.

77. Courrier d'Avignon, October 24, 1777, p. 344; Morning Chronicle, November 8, 1777, p. 2, col. 2; London Chronicle, November 6-8, 1777, p. 454; and London Evening Post, November 6-8, 1777, p. 3, col. 2.

78. Public Advertiser, November 18, 1777, p. 2, col. 3; London Evening Post, November 15-18, 1777, p. 3, col. 1.

79. Gazette de France, November 28, 1777, pp. 479-80; Courrier d'Avignon, December 9, 1777, p. 394; Journal historique et politique, December 10, 1777, p. 407; and Gazeta de Madrid, December 16, 1777, pp. 498-99. 
This reconstruction shows that the stories of Burgoyne's defeat arriving in Europe between mid-October and mid-November 1777 were combined and distorted through a process akin to the children's game of telephone. The arrival of a ship led to rumors, which travelled from one newspaper to another, feeding into "Palais-Royal fabrications." 80 The "false" news anticipated the "real" event-Burgoyne's surrender to General Gates on October 17-but with differences in the date, location, and people involved. The paragraphs did not mention Gates, who had just taken command of the northern army. Instead, they mentioned officers whose names were familiar from previous stories, such as Arnold and St. Clair, both logical choices for a battle that had supposedly occurred at Fort Edward. By contrast, Thomas Conway and the Marquis de la Fayette, though also familiar names, were actually serving with Washington in Pennsylvania, not with Arnold in the North.

Such mistakes influenced subsequent reports. The inclusion of Lafayette's name in paragraphs about Burgoyne's surrender perpetuated a myth in Europe that Lafayette was serving in the North. This myth helped discredit reports of the Battle of Brandywine, the second example here. As usual, news of Washington's defeat first came from ship captains. Upon their arrival in Liverpool and Glasgow, two captains announced the capture of Philadelphia and the deaths of five to seven thousand Americans. ${ }^{81}$ To support their claims, they provided copies of the New York Weekly Mercury dated September 22, 1777. This gazette contained a paragraph reporting the testimonial of a "gentleman" who had just arrived from Philadelphia. He claimed that General Howe had attacked Washington's army on September 11, killing 750 men and wounding two officers. The British army then attacked two other American brigades, raising the total casualties to "5,000 killed, wounded or taken prisoner." According to this "gentleman," when he left Philadelphia the British army was preparing to take the city. ${ }^{82}$ The same New York newspaper contained a letter signed by Washington and published "by order of Congress," which detailed the American defeat at Brandywine. Yet from the moment this letter was reprinted in London newspapers, it was treated as a forgery, discrediting news of the capture of Philadelphia. ${ }^{83}$

The process by which European readers convinced themselves that Washington's letter was not authentic demonstrates that the paragraph was not only a means of transmitting news, but also a tool for analyzing news already in circulation. After the republication of Washington's letter in London, the newspapers contained many paragraphs expressing doubts about its authenticity. First, some readers were hesitant to believe a British victory announced by a New York

80. The phrase was used by Jonathan Williams Jr. in a letter to William Temple Franklin, 27 July 1780, W'TF, vol. 102, fol. 88, American Philosophical Society Library, Philadelphia. 81. Morning Post, November 3, 1777, p. 2, col. 1; Morning Chronicle, November 3, 1777, p. 3, col. 2; and London Chronicle, November 1-4, 1777, p. 438.

82. New York Gazette; and the Weekly Mercury, September 22, 1777, p. 2, col. 1.

83. See the November 4, 1777 issues of London Chronicle, London Evening Post, Morning Chronicle, Morning Post, Public Advertiser, and Gazetteer. 
newspaper because that city was currently under British control. Paragraphs in several newspapers recalled that the New York Gazette had already published news that was later found to be false or exaggerated. ${ }^{84}$ Secondly, Washington's letter claimed that Lafayette had been wounded during the Battle of Brandywine, but because of previous stories about Burgoyne, readers in Europe thought that Lafayette was part of the northern army. ${ }^{85}$ A paragraph in the Public Advertiser, which was later translated in the Courier de l'Europe, quipped: "The Marquis de la Fayette is said to be wounded in two very different and very distant Engagements, both with Washington and with Arnold: The Marquis is said to be a very volatile young man, but with all his Volatility he could scarcely be in both those Places about the same Time." 86

The other problem raised by Washington's letter was that the public did not recognize the author's style. The Morning Post, a ministerial newspaper, and the London Evening Post, an opposition newspaper, each printed the following paragraph:

The letter published in the New York Gawette of the 22nd of September, signed, 'G. Washington,' is reckoned, by no inconsiderable party of politicians, as a hum. Indeed, this epistle is by no means similar to the stile [sic] of that gentleman;- - and the humour of 'the blankets were lost at the men's backs,' who were said to have fallen in the action, and the unmilitary phrase of 'arraying his men behind Chester, for this night' can only be accounted for by supposing that Washington had lost his senses with the field. ${ }^{87}$

As Jack Lynch has shown, concerns about literary forgery became widespread in eighteenth-century Britain. ${ }^{88}$ Some readers were therefore used to examining texts carefully and looking for signs of deception. They tended to be more wary in times of war, when they suspected "speculators" of publishing false news to raise or lower the prices of stocks. ${ }^{89}$ Having already read several letters by Washington printed in the newspapers, readers boasted of their ability to judge the authenticity of this one. In this case, the skeptical readers were correct because the phrase "arraying for this night" did not come from Washington. But far from being the invention of a forger, this "unmilitary phrase" resulted from a printing-shop error.

84. London Evening Post, November 11-13, 1777, p. 3, col. 1; Gazette d'Utrecht, November 18, 1777, p. 4; Gasette de Leyde, supplement, November 11, 1777; Journal historique et politique, November 20, 1777, p. 267 and November 30, 1777, p. 322; and Courrier d'Avignon, November 28, 1777, p. 382.

85. See Public Advertiser, November 3, 1777, p. 3, col. 3.

86. Courrier de l'Europe, November 7, 1777, pp. 366-67; Public Advertiser, November 5, 1777, p. 2, cols. 1-2.

87. Morning Post (November 6, 1777), p. 2, col. 2; London Evening Post (November 4-6, 1777), p. 3, col. 2.

88. Jack Lynch, Deception and Detection in Eighteenth-Century Britain (Hampshire: Ashgate, 2008).

89. Will Slauter, "Forward-Looking Statements: News and Speculation in the Age of the American Revolution,” Journal of Modern History 81 (2009): 759-92. 
As published in American newspapers, the word used by Washington was "arranging," not "arraying." ${ }^{90}$ Compositors worked quickly and one of them, probably in Edinburgh, substituted the letter "y" for the pair "ng." London newspapers perpetuated the mistake because they copied the version that appeared in an Edinburgh newspaper rather than the New York original. The more the letter was analyzed the more it seemed like a forgery; by the time it appeared in Europe, the letter was accompanied by editorial warnings and footnotes pointing out the details that made it suspect. ${ }^{91}$ An error in an Edinburgh printing shop shaped the narrative of the war read in Leiden, Avignon, and Madrid.

What conclusions can be drawn from these detailed examples? The example of Burgoyne's defeat serves as a reminder that false news did not always begin in deceit. The story came together from a range of sources. Upon arrival in Europe, ship captains announced news that inspired paragraphs in the newspapers and the form and content of these reports changed as they traveled from one place to another. It would be wrong to blame individual "paragraph makers" because ultimately the paragraphs read in Avignon or London were collaborative texts, the details of which evolved during the process of writing, translation, and rewriting. Meanwhile, the example of Washington's letter shows that the interpretation as well as the transmission of news was a collective process. One newspaper expressed suspicion about news first printed in New York. Another pointed out apparent contradictions. Then came criticism of the style, which did not match Washington's. The newspapers copied and responded to each other; comments by editors mingled with remarks by readers and "paragraph makers." After two or three days, a consensus emerged: the letter was fake and the British victory doubtful. In fact, the letter was authentic, but the nature of the error was in itself significant: the problem lay not in the critical analysis by readers, which was sound, but in the text itself, which had been corrupted during the process of transmission.

\section{Politics and the Paragraph}

As a reading tool, the paragraph has existed for a long time, but the spread of newspapers during the eighteenth century transformed it into the basic unit of political news. When marked off by white space or indentation, the paragraph facilitated the transmission of texts from one publication to another. By scanning the pages of other newspapers, printers could select paragraphs they wanted to reproduce for their local public. Meanwhile, the paragraph facilitated critical analysis by giving a name to the bits of text that editors and readers confronted.

90. For example, Pennsylvania Packet, September 11, 1777; Pennsylvania Evening Post, September 13, 1777; Boston Gazette, September 22, 1777; and New York Gazette; and the Weekly Mercury, September 22, 1777.

91. Gazette de Leyde, November 11, 14, and 18, 1777; Courrier de l'Europe, November 7, 1777, p. 367; Journal historique et politique, November 20, 1777, pp. 264-68; Courrier d'Avignon, November 25, 1777, p. 378; Gazette d'Utrecht, November 18, 1777; and Gazette d'Amsterdam, November 21, 1777. 
For example, it became convenient to refer to "a paragraph inserted in yesterday's paper" and then give one's opinion on the identity of the author or the credibility of the claims published there.

Indeed, the political uses of the paragraph were numerous at a time when most news circulated anonymously. Beginning in the 1760s in London, the paragraph became a genre in itself, a new type of publication to complement the political pamphlet and the letter to the editor of a newspaper. People referred to paragraph writers who offered their pens to politicians and speculators. They suspected government officials and other individuals of exploiting the culture of anonymity to spread their own versions of events. This notion of the paragraph as a political tool spread from the London of John Wilkes to the Boston of John Adams and beyond. It became familiar to European readers during the American Revolutionary War, when gazettes in all languages filled up with news from England. Cultural intermediaries such as the Courier de l'Europe, based in London but read primarily in France, delivered "paragraphs extracted from English newspapers" to their readers on the continent.

The tradition was renewed in 1789 when the Révolutions de Paris published a section entitled "PARAGRAPHS extracted from several English papers." In this case, the goal was to use English newspapers to track the movements of the "émigrés" and reveal the "secret maneuvers of the royal and aristocratic party."92 The proliferation of newspapers in Paris, which offered direct coverage of the Revolution, caused French-language gazettes printed abroad to lose their subscribers. Yet if the French Revolution marked the end of an era for what Simon Burrows called the "cosmopolitan press," it did not eliminate the role of the paragraph as a vehicle for news and political opinion. ${ }^{93}$ In the United States in the early 1790 s, Jefferson tried to counteract the influence of anti-French news coming from England with paragraphs translated from the Gazette de Leyde. This is but one example, and the multiple and probably contradictory uses of paragraphs during the French Revolution itself would be worthy of study.

As Adams pointed out during the American Revolutionary War, the circulation of paragraphs across an international network of newspapers created new possibilities for the manipulation of public opinion. A paragraph could be inserted in one periodical in the hope that it would be taken up by others. Nevertheless, analysis of the news of Saratoga and Brandywine reveals that this was a complicated game because the "paragraph writers" controlled neither the form in which their writings reappeared nor the meaning that readers gave to them. Editors selected and revised paragraphs. Printers corrected them and arranged them on the page with other paragraphs coming from other places. Readers copied them and retransmitted them, often accompanied by their own comments. 
As for reader involvement in the reporting itself, European gazettes did not publish as many letters to the editor as Anglo-American newspapers. However, the more active role of French editors did not cancel out the participation of readers, whose collective analysis sometimes showed up in the pages of gazettes. Consider this paragraph from the Courier de l'Europe, which would be picked up (and modified) by at least five other gazettes:

The Minister is waiting for dispatches and the majority of the public seems satisfied that they will confirm the favorable opinions that we compiled above. Meanwhile a small minority of this same public, which is not so easily persuaded, is busy evaluating [the credibility of reports] by cross-checking the dates of events, the distances between places, travel times, etc., and here are the most judicious observations that have been published on this subject. They are not all from the same pen, and we collected them from different papers. ${ }^{94}$

The editors who published this mixture of facts and commentary described themselves as "copyists" and "compilers," and they often praised the virtues of impartiality. ${ }^{95}$ Their main sources were scribal newsletters, English newspapers, and European gazettes. The circulation of texts encouraged debate, because as editors copied from each other they also criticized and corrected each other. At the office or the printing shop, they compared and juxtaposed paragraphs. They changed words, deleted sentences, and added commentary, but they rarely cited their sources.

The paragraph was both portable and malleable. As a unit of printing, the paragraph was easily reproduced, but, as a collective work, it was also subject to alteration at each point of transmission. The comparison of periodicals makes it possible to reconstruct publishing practices. The addition or omission of a comma, for example, reveals not only who copied whom, but also how translation and rewriting transformed the news as it circulated. Any analysis of the content of eighteenthcentury newspapers should therefore begin with the collective process by which those papers were composed. The attribution of a newspaper text to an individual author should not be overemphasized, lest it obscure the complex processes that led to the final version(s). To better understand eighteenth-century journalism and to clarify the role of newspapers in the revolutions of the Atlantic World, one must follow the trajectory of the paragraph.

Will Slauter

Centre de recherches historiques (EA 1571)

Université Paris VIII

94. Courrier de l'Europe, November 7, 1777, p. 367; Courier du Bas-Rhin, November 15, 1777, p. 753; Gazette d'Utrecht, November 18, 1777, p. 4; Journal historique et politique, November 20, 1777, pp. 265-68; Courrier d'Avignon, November 21, 1777, p. 376; and Journal Encyclopédique, December 15, 1777, p. 563.

95. See Censer, The French Press in the Age of Enlightenment, chap. 4; Shelly Charles, "Sur l'écriture du présent," in Les gazettes européennes de langue française (XVII'-XVIII ${ }^{e}$ siècle), eds. Henri Duranton et al. (Saint-Étienne: Publications de l'université de Saint-Étienne, 1992), 177-85. 